\title{
TINJAUAN YURIDIS UJARAN KEBENCIAN DIMEDIA SOSIAL DIINJAU DARI UNDANG UNDANG NO 11 TAHUN 2008 TENTANG INFORMASI DAN TRANSAKSI ELEKTRONIK YANG TELAH DIPERBARUI DI DALAM UNDANG UNDANG NO 19 TAHUN 2016 TENTANG INFORMASI DAN TRANSAKSI ELEKTRONIK
}

\author{
Oleh \\ Dody Eko Wijayanto \\ Dosen Fakultas Hukum Universitas Islam Lamomgan
}

\begin{abstract}
Abstrak
Undang-Undang Informasi dan Transaksi Elektronik (UU ITE) adalah ketentuan yang berlaku untuk setiap orang yang melakukan perbuatan hukum sebagaimana diatur dalam Undang-Undang ini, baik yang berada di wilayah hukum Indonesia maupun di luar wilayah hukum Indonesia, yang memiliki akibat hukum di wilayah hukum Indonesia dan/atau di luar wilayah hukum Indonesia dan merugikan kepentingan Indonesia. Rumusan masalah pada penelitian ini meliputi Bagaimana pengaturan komunikasi melalui media sosial menurut UU No 11 Tahun 2008 tentang Informasi dan Transaksi Elektronik dan Bagaimana akibat hukum pelaku pengujar kebencian melalui emedia sosial menurut UU No 11 Tahun 2008 tentang Informasi dan Transaksi Elektronik. Manfaat dari penelitian ini adalah Hasil penelitian ini diharapkan dapat berguna bagi ilmu penhetahuan dan hokum dan Dapat memberikan opini bagi aparat penegak hukum dalam mengambil keputusan. Metode penelitian yang digunakan adalah yuridis normatif dengan pendekatan masalah yaitu pendekatan perundang undangan. Bahan dalam penelitian in menggunakan bahan primer dan sekunder. Sosial media hanya memiliki satu fungsi yaitu untuk menjalin komunikasi secara online.Orang Indonesia adalah salah satu pengguna terbesar yang ada di dunia. Di beberapa media sosial Indonesia menduduki peringkat atas dalam daftar pengguna media sosial paling aktif yang ada di dunia. sementara itu di dunia Komputer dan internet banyak yang namanya tingkatan kejahatan, karena hal itu pemerintah memberikan larangan bagi para pengguna internet khususnya media sosial yang diatur dalam uu no 11 tahun 2008 tentang informasi dan transaksi elektronik di pasal 27 sampai dengan 37. Di Indonesia, istilah ujaran kebencian belum terlalu dipahami. Banyak pihak yang kerap kesulitan membedakan apakah suatu ucapan atau ekspresi termasuk ke dalam kategori ujaran kebencian. Lantas, apa itu sebenarnya ujaran kebencian? Secara umum, ujaran kebencian dapat diartikan sebagai ucapan yang bertujuan untuk menyinggung, menghina, mengintimidasi, atau mengancam seseorang atau suatu kelompok tertentu berdasarkan agama, etnis, ras, gender, kedisabilitasan, atau orientasi seksual. Kepolisian Republik Indonesia telah mengingatkan kepada masyarakat untuk tidak menyebarkan ujaran kebencian dan informasi yang menimbulkan kebencian di media sosial. Selain itu Kepolisian Republik Indonesia telah mengeluarkan Surat Edaran Kapolri Nomor SE/06/X/2015 soal Penanganan Ujaran Kebencian (hate speech).Dalam surat edaran tersebut, penebar kebencian bisa diancam pidana jika tidak mengindahkan teguran dari kepolisian. Penegakan hukum sesuai dengan UU Nomor 11 Tahun 2008 tentang Informasi dan Transaksi Elektronik, UU Nomor 40 Tahun 2008 tentang Penghapusan Diskriminasi Ras dan Etnis, UU Nomor 7 Tahun 2012 tentang Penanganan Konflik Sosial, dan Peraturan Kepala Kepolisian Negara Republik Indonesia Nomor 8 Tahun 2013 tentang Teknis Penanganan Konflik SosiaL. Dari pembahasan bab perbab dapat disimpulkan bahwa pengaturan hukum dan sanksi hukum bagi para pengguna media sosial diatur dalam undang undang nomor 11 tahun 2008 tentang
\end{abstract}


informasi dan transaksi elektronik, sementara saran dari penelitian ini adalah masyarakat sebaiknya lebih berhati hati dalam berkomunikasi melalui media sosial, untuk menginhadri hal hal yang tak di inginkan dan pasal 28 ayat 2 di undang undang nomor 11 tahun 2008 tentang informasi dan transaksi elektronik di buat lebih khusus lagi mengenai tempat di lakukannya pelanggaran tersebut, seperti media sosial.

\section{Kata Kunci : Ujaran Kebencian, media Sosial, Informasi dan Transaksi Elektronik}

\section{PENDAHULUAN}

\section{Latar Belakang}

Perkembangandunia internet pada era saatinimencapaitahap yang begitucepat, sehinggakinibanyaktempat yang sudahmenyediakanlayanan internet sepertiwifi, hotspot dll. Internet telahmenyebarluaskeseluruhdunia, mulaidari pemerintah, pendidikan, ekonomi, bidangkesehatandsb. Pengaksesaninformasi,tukarmenukardata,prosestransaksisecara online dapatdilakukandenganadanya internet. $^{26}$

Undang-Undang Informasi dan Transaksi Elektronik (UU ITE) adalah ketentuan yang berlaku untuk setiap orang yang melakukan perbuatan hukum sebagaimana diatur dalam Undang-Undang ini, baik yang berada di wilayah hukum Indonesia maupun di luar wilayah hukum Indonesia, yang memiliki akibat hukum di wilayah hukum Indonesia dan/atau di luar wilayah hukum Indonesia dan merugikan kepentingan Indonesia.

UU ITE pada dasarnya menata, mengelola, dan mengatur segala bentuk kegiatan penggunaan informasi dan transaksi elektronik yang berlangsung di dunia maya dan dilakukan dengan menggunakan komputer atau media elektronik lainnya. Transaksi elektronik yang dimaksud adalah perbuatan hukum yang dilakukan

\footnotetext{
${ }^{26}$ https://isnaenisofi19.wordpress.com/2015/10/01/ makalah-analisa-uu-ite-no-11-tahun-2008/
}

dengan menggunakan komputer, jaringan komputer, atau media elektronik lainnya. Yang tergolong informasi dalam UU ini tak terbatas pada tulisan, gambar atau suara, tapi juga e-mail, telegram dan lainnya

UU ITE ini tidak mau kompromi terhadap para pelanggarnya. Demikian juga terhadap pendistribusian informasi yang mengandung muatan informasi yang ditujukan untuk menimbulkan rasa kebencian atau permusuhan. Larangan ini tertuang diPasal 28 ayat (1) atau ayat (2) Adapun sanksinya, sebagaimana tertulis di Pasal 45, adalah dipidana dengan pidana penjara paling lama 6 (enam) tahun dan/atau denda paling banyak Rp1.000.000.000,00 (satu miliar rupiah). ${ }^{27}$

Sementara itu media sosial banyak digunakan oleh masyarakat dunia khususnya Indonesia, bisa kita temukan melalui mesin pencari seperti Google atau Mozilla firefox dan yang lainnya, namun yang paling populer dikalangan para pengguna media sosial diantaranya adalah Facebook, Twitter, BBM, WhatsApp, Instagram, dan banyak yang lainnya. Permasalahan hukum yang sering kali dihadapi adalah ketika terkait dengan penyampaian informasi, komunikasi dan/atau data secara elektronik, khususnya dalam hal pembuktian dan

\footnotetext{
${ }^{27}$ https://zulianaistichomah.wordpress.com/2013/05/ 29/tinjauan-uu-no-11-tahun-2008-tentanginformasi-dan-transaksi-elektronik-dalam-kasuscyber-crime-oleh-iwan-piliang-berdasarkan-teorihukum-pidana/
} 
hal yang terkait dengan perbuatan hukum yang dilaksanakan melalui sistem elektronik. Sebagai akibat dari perkembangan yang demikian, maka lambat laun, teknologi informasi dengan sendirinya juga telah mengubah perilaku masyarakat dari peradaban manusia secara global.

Namun, perkembangan teknologi tidak hanya berupa memberikan dampak positif saja, namun juga memberikan dampak negatif, tindak pidana penghinaan atau ujaran kebencian (hate speech) dan/atau penghinaan, serta penyebaran informasi di media sosial yang ditujukan untuk menimbulkan rasa kebencian atau permusuhan antar individu dan/atau kelompok masyarakat tertentu berdasarkan atas suku, agama, ras dan antargolongan (SARA). Tindak pidana tersebut selain menimbulkan dampak yang tidak baik juga dapat merugikan korban dalam hal pencemaran nama baik, dengan modus operandi menghina korban dengan menggunakan kata-kata maupun gambar yang menghina dengan ujaran kebencian. Sehingga dalam kasus ini diperlukan adanya ketegasan pada tindak pidana tersebut, agar tidak terjadikesalahpahaman yang akhirnya merugikan masyarakat. ${ }^{28}$

\section{".Tujuan Penelitian}

Berdasarkan rumusan masalah diatas, maka penulisan penelitian ini bertujuan untuk:

1. Tujuan Obyektif

a. Untuk mengetahui tentang ujaran kebencian di media sosial.

b. Untuk mengetahui sanksi terhadap pelaku pengujar kebencian di media sosial.

2. Tujuan Subyektif a. Untuk menambah ilmu pengetahuan serta pemahaman penulis terhadap narkotika.

Untuk berkontribusi dalam pemikiran bagi ilmu hukum.

\section{METODE PENELITIAN}

\section{Type Penelitian}

Metode penelitian yang dipakai adalah metode penelitian hukum normatif atau peneltian hukum kepustakaan yaitu penelitian hukum yang dilakukan dengan cara meneliti undang undang dan data sekunder.bahan -bahan tersebut disusun secara sistematis untuk memepercepat dalam mengambil simpulan dari permasalahan yang diteliti.

\section{Pendekatan Masalah}

Pendekatan masalah penelitian ini menggunakan pendekatan yuridis normatif. Pendekatan ini ialah pendekatan terhadap peraturan perundang-undangan yang ada.

Selain itu digunakan pendekatan yang lainnya guna mempermudah analisia ilmiah yang dibutuhkandalam permasalahan ini dalam pendekatan penelitan yuridis normatif.

\section{Bahan Hukum}

Bahan hukum dari penelitian hukum normatif yang dikaji adalah bahan hukum yang berisi peraturan normative yaitu bahan-bahan hukum yang terdiri dari bahan hukum primer dan sekunder yaitu:

a. Bahan Hukum Primer

- Undang-Undang Dasar Republik Indonesia Tahun 1945.

- Kitab Undang-Undang Hukum Pidana (KUHP).

- Undang-Undang No. 11 Tahun 2008 Tentang Informasi dan Transaksi Elektronik

b. Bahan Hukum Sekunder

- Jurnal penelitian hukum.

\footnotetext{
${ }^{28}$ Digilib.uinsby.ac.id/12426/4/bab\%201.pdf
} 
- Buku-buku tentang UU IT.

- Website resmi yang membahas permasalahan ini.

\section{Prosedur Pengumpulan Bahan Hukum}

Dalam penelitian ini yang digunakan yang digunakan adalah penelitian hukum normatif atau penelitian hukum kepustakaan, maka dalam pengumpulan bahan hukum penulis menggunakan bahan hukum primer maupun bahan hukum sekunder untuk membahas permasalahan dalam penelitian ini.Dengan begitu akan mempermudah dalam menyelesaikan permasalahan yang ada dan dapat mempercepat proses penulisan penelitian ini.

\section{Pengolahan dan Analisis Bahan Hukum}

Analisis yang digunakan adalah analisis deskripstif , yang di mulai dengan mengelompokkan data yang dilakukan secara induksi sehingga memberikan hasil secara sempurna, untuk memperoleh informasi yang akurat dengan begitu penelitian dapat lebih terfokus pada masalah yang spesifik.selain itu dapat memudahkan penulis dalam menganalisa data yang sudah lengkap dan yang telah dikumpulkan.

\section{HASIL PENELITIAN DAN PEMBAHASAN \\ PENGATURAN KOMUNIKASI MELALUI MEDIA SOSIAL MENURUT UNDANG UNDANG NO 11 TAHUN 2008 TENTANG INFORMASI DAN TRANSAKSI ELEKTRONIK}

Di jaman modern ini seseorang banyak memakai alat-alat elek tronik canggih yang dapat mempermudah sebuah aktifitas yang mana seseorang membutuhkannya, dalam dunia computer maupun di dunia internet, banyak sekali orang yang melakukan aktifitas kejahatannya demi sebuah keuntungan yang lebih besar. Sering kali pelaku kejahatan ini bukan di istilahkan sebagai perampokan atau juga pelaku kejahatan yang ada di duni anyata, pelaku tersebut banyak orang yang mengistilahkan dengan Hacker atau Hacking, sepintas nama tersebut sudah tenar sejak lama dan nama tersebut paling di takuti di dalam dunia computer maupun internet, jika seseorang mendengar nama itu maka semua akan kaget dan takut kalau akun dan privasi mereka akan di lihat oleh pelaku Hacker. Di dunia Komputer dan internet banyak yang namanya tingkatan kejahatan, karena hal itu pemerintah memberikan larangan bagi para pengguna internet khususnya media sosial yang diatur dalam uu no 11 tahun 2008 tentang informasi dan transaksi elektronik di pasal 27 sampai dengan 37 yang bunyinya sebagai berikut :

Pasal 27

(1) Setiap Orang dengan sengaja dan tanpa hak mendistribusikan dan/atau mentransmisikan dan/atau membuat dapat diaksesnya Informasi Elektronik dan/atau Dokumen Elektronik yang memiliki muatan yang melanggar kesusilaan.

(2) Setiap Orang dengan sengaja dan tanpa hak mendistribusikan dan/atau mentransmisikan dan/atau membuat dapat diaksesnya Informasi Elektronik dan/atau Dokumen Elektronik yang memiliki muatan perjudian.

(3) Setiap Orang dengan sengaja dan tanpa hak mendistribusikan dan/atau mentransmisikan dan/atau membuat dapat diaksesnya Informasi Elektronik dan/atau Dokumen Elektronik yang memiliki muatan penghinaan dan/atau pencemaran nama baik.

(4) Setiap Orang dengan sengaja dan tanpa hak mendistribusikan dan/atau 
mentransmisikan dan/atau membuat dapat diaksesnya Informasi Elektronik dan/atau Dokumen Elektronik yang memiliki muatan pemerasan dan/atau pengancaman.

Pasal 28...

Pasal 28

(1) Setiap Orang dengan sengaja dan tanpa hak menyebarkan berita bohong dan menyesatkan yang mengakibatkan kerugian konsumen dalam Transaksi Elektronik.

(2) Setiap Orang dengan sengaja dan tanpa hak menyebarkan informasi yang ditujukan untuk menimbulkan rasa kebencian atau permusuhan individu dan/atau kelompok masyarakat tertentu berdasarkan atas suku, agama, ras, dan antargolongan (SARA).

Pasal 29

Setiap Orang dengan sengaja dan tanpa hak mengirimkan Informasi Elektronik dan/atau Dokumen Elektronik yang berisi ancaman kekerasan atau menakut-nakuti yang ditujukan secara pribadi.

Pasal 30

(1) Setiap Orang dengan sengaja dan tanpa hak atau melawan hukum mengakses Komputer dan/atau Sistem Elektronik milik Orang lain dengan cara apa pun.

(2) Setiap Orang dengan sengaja dan tanpa hak atau melawan hukum mengakses Komputer dan/atau Sistem Elektronik dengan cara apa pun dengan tujuan untuk memperoleh Informasi Elektronik dan/atau Dokumen Elektronik.

(3) Setiap Orang dengan sengaja dan tanpa hak atau melawan hukum mengakses Komputer dan/atau Sistem Elektronik dengan cara apa pun dengan melanggar, menerobos, melampaui, atau menjebol sistem pengamanan.

Pasal 31

(1) Setiap Orang dengan sengaja dan tanpa hak atau melawan hukum melakukan intersepsi atau penyadapan atas Informasi Elektronik dan/atau Dokumen Elektronik dalam suatu Komputer dan/atau Sistem Elektronik tertentu milik Orang lain.

(2) Setiap ...

(2) Setiap Orang dengan sengaja dan tanpa hak atau melawan hukum melakukan intersepsi atas transmisi Informasi Elektronik dan/atau Dokumen Elektronik yang tidak bersifat publik dari, ke, dan di dalam suatu Komputer dan/atau Sistem Elektronik tertentu milik Orang lain, baik yang tidak menyebabkan perubahan apa pun maupun yang menyebabkan adanya perubahan, penghilangan, dan/atau penghentian Informasi Elektronik dan/atau Dokumen Elektronik yang sedang ditransmisikan.

(3) Kecuali intersepsi sebagaimana dimaksud pada ayat (1) dan ayat (2), intersepsi yang dilakukan dalam rangka penegakan hukum atas permintaan kepolisian, kejaksaan, dan/atau institusi penegak hukum lainnya yang ditetapkan berdasarkan undang-undang.

(4) Ketentuan lebih lanjut mengenai tata cara intersepsi sebagaimana dimaksud pada ayat (3) diatur dengan Peraturan Pemerintah.

Pasal 32

(1) Setiap Orang dengan sengaja dan tanpa hak atau melawan hukum dengan cara apa pun mengubah, menambah, mengurangi, melakukan transmisi, merusak, menghilangkan, memindahkan, menyembunyikan suatu Informasi Elektronik dan/atau 
Dokumen Elektronik milik Orang lain atau milik publik.

(2) Setiap Orang dengan sengaja dan tanpa hak atau melawan hukum dengan cara apa pun memindahkan atau mentransfer Informasi Elektronik dan/atau Dokumen Elektronik kepada Sistem Elektronik Orang lain yang tidak berhak.

(3) Terhadap perbuatan sebagaimana dimaksud pada ayat (1) yang mengakibatkan terbukanya suatu Informasi Elektronik dan/atau Dokumen Elektronik yang bersifat rahasia menjadi dapat diakses oleh publik dengan keutuhan data yang tidak sebagaimana mestinya.

Pasal 33

Setiap Orang dengan sengaja dan tanpa hak atau melawan hukum melakukan tindakan apa pun yang berakibat terganggunya Sistem Elektronik dan/atau mengakibatkan Sistem Elektronik menjadi tidak bekerja sebagaimana mestinya.

Pasal 34

(1) Setiap Orang dengan sengaja dan tanpa hak atau melawan hukum memproduksi, menjual, mengadakan untuk digunakan, mengimpor, mendistribusikan, menyediakan, atau memiliki:

a. perangkat keras atau perangkat lunak Komputer yang dirancang atau secara khusus dikembangkan untuk memfasilitasi perbuatan sebagaimana dimaksud dalam

Pasal 27 sampai dengan Pasal 33;

b. sandi lewat Komputer, Kode Akses, atau hal yang sejenis dengan itu yang ditujukan agar Sistem Elektronik menjadi dapat diakses dengan tujuan memfasilitasi perbuatan sebagaimana dimaksud dalam Pasal 27 sampai dengan Pasal 33.
(2) Tindakan sebagaimana dimaksud pada ayat (1) bukan tindak pidana jika ditujukan untuk melakukan kegiatan penelitian, pengujian Sistem Elektronik, untuk perlindungan Sistem Elektronik itu sendiri secara sah dan tidak melawan hukum.

Pasal 35

Setiap Orang dengan sengaja dan tanpa hak atau melawan hukum melakukan manipulasi, penciptaan, perubahan, penghilangan, pengrusakan Informasi Elektronik dan/atau Dokumen Elektronik dengan tujuan agar Informasi Elektronik dan/atau Dokumen Elektronik tersebut dianggap seolah-olah data yang otentik.

Pasal 36

Setiap Orang dengan sengaja dan tanpa hak atau melawan hukum melakukan perbuatan sebagaimana dimaksud dalam Pasal 27 sampai dengan Pasal 34 yang mengakibatkan kerugian bagi Orang lain.

\section{Pasal 37}

Setiap Orang dengan sengaja melakukan perbuatan yang dilarang sebagaimana dimaksud dalam Pasal 27 sampai dengan Pasal 36 di luar wilayah Indonesia terhadap Sistem Elektronik yang berada di wilayah yurisdiksi Indonesia.

\section{AKIBAT HUKUMPELAKU PENGUJAR KEBENCIAN MELALUI MEDIA SOSIAL MENURUT UNDANG UNDANG NO 11 TAHUN 2008 TENTANG INFORMASI DAN TRANSAKSI ELEKTRONIK}

$\begin{gathered}\text { Media sosial } \begin{array}{r}\text { memang } \\ \text { orang-orang } \\ \text { gemfasilitasi }\end{array} \\ \text { untuk mengekspresikan } \\ \text { Kendati demikian, media sosial juga } \\ \text { dapat menjelma buah simalakama. }\end{gathered}$
Beberapa orang mesti berurusan


dengan hukum gara-gara menumpahkan isi kepala dan perasaannya terhadap pihak tertentu.

Di Indonesia, istilah ujaran kebencian belum terlalu dipahami. Banyak pihak yang kerap kesulitan membedakan apakah suatu ucapan atau ekspresi termasuk ke dalam kategori ujaran kebencian. Lantas, apa itu sebenarnya ujaran kebencian? Secara umum, ujaran kebencian dapat diartikan sebagai ucapan yang bertujuan untuk menyinggung, menghina, mengintimidasi, atau mengancam seseorang atau suatu kelompok tertentu berdasarkan agama, etnis, ras, gender, kedisabilitasan, atau orientasi seksual.

Ujaran kebencian yang saat ini marak terjadi mempunyai potensi untuk menciderai penghormatan terhadap kemajemukan dan keberagaman yang menjadi nilai pokok masyarakat Indonesia. Seperti yang diidentifikasikan oleh Komnas HAM, ujaran kebencian membuka peluang bagi berkembangnya praktik diskriminasi dan kekerasan terhadap kelompok agama, ras, dan etnis minoritas, bahkan jika dibiarkan tanpa kendali bisa mendorong tindak kekerasan terhadap kelompok minoritas. $^{29}$

Ketika Kepala Polisi RI Jenderal Badrodin Haiti mengeluarkan Surat Edaran (SE) No. SE/6/X/2015 tentang Penanganan Ujaran Kebencian. aturan tentang ujaran kebencian (hate speech). Ini berlaku sejak 8 Oktober 2015

Hate speech atau ujaran kebencian dalam konteks sosiologis masyarakat Indonesia bisa jadi merupakan hal yang biasa. Sama

${ }^{29}$ http://www.tifafoundation.org/menangkal-ujarankebencian/ halnya ketika orang melakukan 'rumpian', 'rerasan', 'gosip', atau bentuk-bentuk obrolan masyarakat di komunitas warung kopi, 'cangkrukan' atau di sudut-sudut jalan. Surat edaran sendiri memiliki fungsi sebagai alat atau cara untuk mengontrol tindakan anggota masyarakat yang dianggap keluar dari batas norma. Rumpian, rerasan atau gosip itu menjadi kontrol sosial yang efektif bila dilakukan pada komunitas komunal dengan tipe masyarakat bersolidaritas mekanis, di mana hubungan-hubungan sosial di antara anggotanya begitu intim atau dekat. $^{30}$

Pro-kontra mencuat di kalangan masyarakat terkait Surat Edaran (SE) Kapolri No SE/06/X/2015 tentang penanganan 'ujaran kebencian' (hate speech) di ranah publik. Ada tujuh bentuk ujaran kebencian disebut dalam SE: penghinaan, pencemaran nama baik, penistaan, perbuatan tidak menyenangkan, memprovokasi, menghasut, dan menyebarkan berita bohong. Semua tindakan ini memiliki tujuan atau berdampak pada tindak diskriminasi, kekerasan, penghilangan nyawa, dan atau konflik sosial. Dalam SE dinyatakan, ujaran kebencian bertujuan menghasut dan menyulut kebencian terhadap individu dan atau kelompok masyarakat/komunitas berbeda dalam aspek: suku, agama, ajaran keagamaan, keyakinan atau kepercayaan, ras, antar-golongan, warna kulit, etnis, gender, difabel, dan orientasi seksual. Ujaran kebencian bisa tersampaikan melalui berbagai media, antara lain: orasi kegiatan kampanye [politik], spanduk atau banner, jejaring media sosial, penyampaian pendapat di muka umum (demonstrasi), ceramah

\footnotetext{
${ }^{30}$ geotimes.co.id/ujaran-kebencian-dalam-pusaranruang-publik/
} 
keagamaan, media massa cetak maupun elektronik, dan pamphlet. ${ }^{31}$

$$
\begin{aligned}
& \text { Kepolisian Republik Indonesia } \\
& \text { telah mengingatkan kepada } \\
& \text { masyarakat untuk tidak menyebarkan } \\
& \text { ujaran kebencian dan informasi yang } \\
& \text { menimbulkan kebencian di media } \\
& \text { sosial. }
\end{aligned}
$$

"Setiap orang dengan sengaja dan tanpa hak menyebarkan informasi yang ditujukan untuk menimbulkan rasa kebencian atau permusuhan individu dan/atau kelompok masyarakat tertentu berdasarkan atas suku, agama, ras, dan antargolongan (SARA)," bunyi ayat 2 pasal 28 UU ITE.

Dalam bab ketentuan pidana pada UU ITE tercantum rincian ancaman pidana.

Pasal 45 atau 2 UU ITE berbunyi setiap orang yang memenuhi unsur yang dimaksud dalam pasal 28 ayat 1 atau ayat 2 maka dipidana penjara paling lama enam tahun dan atau denda paling banyak Rp1 miliar. ${ }^{32}$

Selain itu Kepolisian Republik Indonesia telah mengeluarkan Surat Edaran Kapolri Nomor SE/06/X/2015 soal Penanganan Ujaran Kebencian (hate speech).Dalam surat edaran tersebut, penebar kebencian bisa diancam pidana jika tidak mengindahkan teguran dari kepolisian. Penegakan hukum sesuai dengan: 1.

KUHP,

2. UU Nomor 11 Tahun 2008 tentang Informasi dan Transaksi Elektronik, 3. UU Nomor 40 Tahun 2008 tentang

\footnotetext{
${ }^{31}$ http://www.republika.co.id/berita/kolom/resonans i/15/11/04/nxaiq7319-ujaran-kebencian-dankebebasan

${ }^{32}$ Kitab Undang Undang Hukum Pidana
}

Penghapusan Diskriminasi Ras dan Etnis,

4. UU Nomor 7 Tahun 2012 tentang Penanganan Konflik Sosial, dan 5. Peraturan Kepala Kepolisian Negara Republik Indonesia Nomor 8 Tahun 2013 tentang Teknis Penanganan Konflik Sosial.

Berikut poin-poin krusial dalam SE Kapolri soal penanganan ujaran kebencian atau hate speech Nomor SE/06/X/2015 yang diteken pada 8 Oktober lalu.

Bentuk Ujaran Kebencian.

Pada Nomor 2 huruf (f) SE itu, disebutkan bahwa "ujaran kebencian dapat berupa tindak pidana yang diatur dalam Kitab Undang-Undang Hukum Pidana (KUHP) dan ketentuan pidana lainnya di luar KUHP, yang berbentuk antara lain:

1. Penghinaan,

2. Pencemaran nama baik,

3. Penistaan,

4. Perbuatan tidak menyenangkan,

5. Memprovokasi,

6. Menghasut,

7. Menyebarkan berita bohong dan semua tindakan di atas memiliki tujuan atau bisa berdampak pada tindak diskriminasi, kekerasan, penghilangan nyawa, dan atau konflik sosial".

\section{Aspek Ujaran Kebencian}

Selanjutnya, pada huruf (g) disebutkan bahwa ujaran kebencian sebagaimana dimaksud di atas bertujuan untuk menghasut dan menyulut kebencian terhadap individu dan atau kelompok masyarakat dalam berbagai komunitas yang dibedakan dari aspek:

1. Suku,

2. Agama,

3. Aliran keagamaan,

4. Keyakinan atau kepercayaan, 
5. Ras,

6. Antargolongan,

7. Warna kulit,

8. Etnis,

9. Gender,

10. Kaum difabel,

11. Orientasi seksual.

\section{Media Ujaran Kebencian}

Kemudian, pada huruf (h) disebutkan bahwa "ujaran kebencian sebagaimana dimaksud di atas dapat dilakukan melalui berbagai media, antara lain:

1. Dalam orasi kegiatan kampanye,

2. Spanduk atau banner,

3. Jejaring media sosial,

4. Penyampaian pendapat di muka umum (demonstrasi),

5. Ceramah keagamaan,

6. Media massa cetak atau elektronik,

7. Pamflet.

Pada huruf (i), disebutkan bahwa "dengan memperhatikan pengertian ujaran kebencian di atas, perbuatan ujaran kebencian apabila tidak ditangani dengan efektif, efisien, dan sesuai dengan ketentuan peraturan perundang-undangan, akan berpotensi memunculkan konflik sosial yang meluas, dan berpotensi menimbulkan tindak diskriminasi, kekerasan, dan atau penghilangan nyawa".

Prosedur penanganan

Adapun, pada nomor 3 SE itu, diatur pula prosedur polisi dalam menangani perkara yang didasari pada hate speech agar tidak menimbulkan diskriminasi, kekerasan, penghilangan nyawa dan atau konflik sosial yang meluas.

Pertama, setiap personel Polri diharapkan mempunyai pemahaman dan pengetahuan mengenai bentukbentuk kebencian.
Kedua, personel Polri diharapkan lebih responsif atau peka terhadap gejala-gejala di masyarakat yang berpotensi menimbulkan tindak pidana.

Ketiga, setiap personel Polri melakukan kegiatan analisis atau kajian terhadap situasi dan kondisi di lingkungannya. Terutama yang berkaitan dengan perbuatan ujaran kebencian.

Keempat, setiap personel Polri melaporkan ke pimpinan masingmasing terhadap situasi dan kondisi di lingkungannya, terutama yang berkaitan dengan perbuatan ujaran kebencian.

Apabila ditemukan perbuatan yang berpotensi mengarah ke tindak pidana ujaran

kebencian, maka setiap anggota Polri wajib melakukan tindakan, antara lain:

- Memonitor dan mendeteksi sedini mungkin timbulnya benih pertikaian di masyarakat,

- Melakukan pendekatan pada pihak yang diduga melakukan ujaran kebencian,

- Mempertemukan pihak yang diduga melakukan ujaran kebencian dengan korban ujaran kebencian, - Mencari solusi perdamaian antara pihak-pihak yang bertikai dan memberikan pemahaman mengenai dampak yang akan timbul dari ujaran kebencian di masyarakat;

Jika tindakan preventif sudah dilakukan namun tidak menyelesaikan masalah, maka penyelesaiannya dapat dilakukan melalui upaya penegakan hukum sesuai dengan: - KUHP,

- UU Nomor 11 Tahun 2008 tentang Informasi dan Transaksi Elektronik, - UU Nomor 40 Tahun 2008 tentang 
Penghapusan Diskriminasi Ras dan Etnis,

- UU Nomor 7 Tahun 2012 tentang Penanganan Konflik Sosial, dan - Peraturan Kepala Kepolisian Negara Republik Indonesia Nomor 8 Tahun 2013 tentang Teknis Penanganan Konflik Sosial. ${ }^{33}$

\section{Simpulan}

\section{PENUTUP (KESIMPULAN)}

Komunikasi merupakan sebuah aktivitasyang tak bisa dipisahkan dari kehidupan sosial masyarakat,bisa dipastikan sebagian besar kegiatan masyarakat dari kehidupan kita menggunakan komunikasi sebagai alat penyampai pesan. Di era modern seperti sekarang ini masyarakat diberikan banyak pilihan untuk melakukan aktivitas berkomunikasi, salah satunya adalah melalui media sosial. Seperti yang kita tau saat ini sangat di gandrungi masyarakat khususnya di kalangan muda dan mudi. Semua itu dikarenakan mudahnya msayarakat mengakses media sosial. Di balik mudahnya kita mengakses atau menggunakan media sosial ada beberapa hal yang harus kita perhatikan dari syarat, aturan sampai larangan yang telah diatur dalam pengaturan internal setiap media sosial yang kita miliki. Kenyamanan dan keamanan bagi setiap pengguna media sosial merupakan sebuah alasan utama kenapa semua itu harus kita perhatikan.

Kemudahan dalam mengakses atau menggunakan media sosial sering kali membuat para penggunanya, sehingga dapat membuat para penggunanya lupa bahwasanya banyak peristiwa atau kejadian yang berujung pada hukuman pidana. Salah satunya adalah ujaran kebencian yang sering terjadi, baik yang bersifat individu satu dan individu lain atau kelompok satu dan kelompok lain. Hal hal semacam itulah yang membuat

\footnotetext{
${ }^{33}$ Surat Edaran Kapolri Nomor SE/06/X/2015
}

pemerintah membuat sebuah peraturan yang dimuat dalam undang undan nomor 11 tahun 2008 tentang informasi dan transaksi elektronik. Mengenai masalah ujaran kebencian di kaji lebih mendalam di dalam pasal 28 ayat 2 jo pasal 45 undang undang nomor 11 tahun 2008 tentang informasi dan transaksi elektronik.

\section{Saran}

Mudahnya kita mengakses media sosial mampu membuat kita lupa bahwasanya segala sesuatu yang kita perbuat di media sosial ada aturannya, karena hal itu masyarakat sebaiknya lebih berhati hati dalam berkomunikasi melalui media sosial, untuk menginhadri hal hal yang tak di inginkan.

Masih banyaknya pelanggaran yang menyangkut unsur suku, agama, rasa atau yang lainnya seharusnya pasal 28 ayat 2 di undang undang nomor 11 tahun 2008 tentang informasi dan transaksi elektronik di buat lebih khusus lagi mengenai tempat di lakukannya pelanggaran tersebut, seperti media sosial dan lain sebagainya.

\section{DAFTAR PUSTAKA}

- Kitab Undang-Undang Hukum Pidana.

- Undang Undang Nomor 11 Tahun 2011 Tentang Informasi dan Transaksi Elektronik

- Undang Undang Nomor 19 Tahun 2016 Tentang Informasi dan Transaksi Elektronik

- Surat Edaran Kapolri NOMOR SE/06/X/2015 tentang Ujaran Kebencian (Hate Speech)

- https://zulianaistichomah.wordpres s.com/2013/05/29/tinjauan-uu-no11-tahun-2008-tentang-informasidan-transaksi-elektronik-dalamkasus-cyber-crime-oleh-iwanpiliang-berdasarkan-teori-hukumpidana/ 
- https://isnaenisofi19.wordpress.co $\mathrm{m} / 2015 / 10 / 01 / \mathrm{makalah}-$ analisa-uuite-no-11-tahun-2008/

- http://www.suduthukum.com/2016/ 11/tinjauan-tentang-ujarankebencian-hate.html

- Digilib.uinsby.ac.id/12426/4/bab\% 201.pdf

- http://www.suduthukum.com/2016/ 11/tinjauan-tentang-ujarankebencian-hate.html

- https://id.wikipedia.org/wiki/Media sosial

- //www.trigonalmedia.com/2015/08/ pengertian-media-sosial-menurutpara.html
- http://www.suduthukum.com/2016/ 11/tinjauan-tentang-ujarankebencian-hate.html

- http://www.tifafoundation.org/men angkal-ujaran-kebencian/

- geotimes.co.id/ujaran-kebenciandalam-pusaran-ruang-publik/

- http://www.republika.co.id/berita/k olom/resonansi/15/11/04/nxaiq731 9-ujaran-kebencian-dan-kebebasan 